TP Periodica Polytechnica

Social and Management

Sciences

25(2), pp. 141-149, 2017

https://doi.org/10.3311/PPso.10049

Creative Commons Attribution (i)

RESEARCH ARTICLE

\section{Factors Influencing Life Insurance Market Development in Montenegro}

\author{
Milijana Novovic Buric ${ }^{1 *}$, Maja Bacovic ${ }^{1}$, Julija Cerovic ${ }^{1}$, \\ Milena Lipovina Bozovic ${ }^{1}$
}

Received 22 September 2016; accepted after revision 23 January 2017

\begin{abstract}
Montenegrin insurance market is in a low level of development compared to developed countries, with dominant share of non-life insurance. There are many factors influencing the insufficient development of life insurance in Montenegro. This manuscript offers an analysis of significant factors that have important impact on life insurance products purchase. In order to prove the hypotheses established in the manuscript, based on the survey, chi square test of independency and regression analysis were carried out. Testing results showed that age structure and education as demographic factors as well as level of employment as economic factor highly influence demand for life insurance in Montenegro while there is no evidence that different trust in insurance system, gender and region influenced purchase of life insurance.
\end{abstract}

\section{Keywords}

life insurance, insurance market, demographic and economic factors, chi square test

\footnotetext{
${ }^{1}$ Faculty of Economics, University of Montenegro,

Jovana Tomasevica 37, 81000 Podgorica, Montenegro

*Corresponding author, e-mail: mnovovic@ac.me
}

\section{Introduction}

Due to low life standard, insufficient development and instability of financial market, the lack of awareness among citizens regarding the importance and benefits of risk coverage through insurance, Montenegrin insurance market is characterized by non-life insurance being dominantly represented within total market portfolio. Demographic and economic factors affect insurance market trends significantly, especially life insurance, which includes not only risk coverage, but also savings component. In contrast to the population of developed countries and due to overall economic and political circumstances both in the country and in the region, Montenegrin citizens have not developed a habit of thinking about safe saving, i.e. future.

Although the insurance market in Montenegro follows moderate growth trends, it is still on a low level of development compared to developed economies. During 2015, there were 11 insurance companies on Montenegrin insurance market, among which six companies dealt only with life insurance business. Since Montenegro obtained independency in 2006, there has been an obvious and significant growth of life insurance premium, but still insufficient. As realized gross life insurance premium in 2006 amounted to less than 2 million $€$, it can be concluded that by the end of 2015, it had increased by about 6.5 times, amounting to 13 million $€$. The most represented type of whole life insurance activities ${ }^{1}$ is life insurance where in year 2015 insurance companies wrote 11.5 million $€$ worth gross premium, with the share of $89 \%$ in total life insurance premium. $^{2}$

The aim of this manuscript is to indicate to the most important factors determining life insurance trends in Montenegro. These can be observed as demographic, economic and other factors.

1 Life insurance activities, depending on the risk covered, shall be grouped into the following classes of insurance: 1) Life insurance; 2) Annuity insurance; 3) Supplemental insurance in addition to life insurance; 4) Other classes of life insurance; (Insurance Law, Official Gazette of Montenegro, No 53/09, 73/10, 40/11, 45/12, 06/13, Article no.9)

2 Gross premium by Type of Insurance and by Insurance Company in 2015(preliminary data), Insurance Supervision Agency, February 2016. 
At the beginning of the $21^{\text {th }}$ century, the most developed and some developing countries were facing population aging, which is the result of fertility decline, followed by low death rates of the older population. Population aging has a negative impact on labour market structure, saving rate and fiscal system. From demographic perspective (i.e. Theory of Demographic Transition), most countries have approached the post-transition phase (zero rates of population growth) or even the future-declining phase (negative population growth rates). Both phases are followed by a period of population aging, which becomes intense when a country approaches the future-declining phase. The population in Montenegro was estimated up to $2091^{3}$, based on cohort components method. Projections have shown that, at the beginning of the $21^{\text {st }}$ century, Montenegro is approaching a post-transition demographic era, characterized by an almost equal crude birth rate and crude death rate, and both slightly higher than 10 per thousand people. The post-transition period should end in the fifth decade, when the "future declining" period starts with a constant decline in population, low fertility rates and aging. Related to life insurance, demographic trends may have a negative impact on savings, as aged populations usually have negative savings and invest less in any form of saving funds. On the other hand, an older population can have a positive impact on life insurance premium growth due to the necessity to secure successors and also to secure better life conditions for the period when there is no more work activities. The analyses of life standard, employment and education in Montenegro, show that the middle aged population gives the biggest contribution to life insurance in Montenegro.

Education also has a significant influence on savings through life insurance products. Program of economic education is very important for the development of life insurance and it should include insurance as an economic, technical and legal discipline, so that the citizens can understand life insurance as a product, their own rights and obligations as well as the expectations regarding insurance sum payment depending on risk realization, guaranteed interest rate included in the calculation of premium, and the interest rate on financial market. The number of graduates in Montenegro coming from economics major makes $10 \%$ of total graduates, on average, which is a significant share and has importance in developing and strengthening life insurance system. In Montenegro, insurance has been studied seriously since 2006, when very important reforms of insurance market began and since when there has been life insurance positive growth trend.

Unemployment rate had been decreasing in Montenegro until 2009, while since 2010 (global financial crisis) it fluctuates seasonally, and has slightly increased. According to labour

3 For more details see: Maja Bacovic: "Demographic Changes in transition countries: Opportunity or Obstacle for Economic Growth: case of Montenegro", European Research Studies, Vol X, issue 3-4, 2007, ISSN: 1108-2976, pages 31-44 force survey, it is estimated around 19\%, while some other administrative sources show lower figures. However, it is higher than desired, and has to be lower in order to have a positive influence on national savings and investment in life insurance.

It is also important to emphasize that there are significant regional inequalities in Montenegro, with northern region significantly less developed (unemployment rate is more than $30 \%$ ), compared to more developed central and southern region.

World events and the negative effects of the financial crisis did have a certain impact on the business of insurance companies. The impact of the crisis reflected on citizens' reliance on all participants of financial market and therefore the insurance companies as well. Since the insurance companies in Montenegro did not invest in financial derivatives and other financial instruments traded on stock exchange markets worldwide (in accordance with the Rulebook on Depositing and Investing Technical Reserves and Insurance Companies Assets, Insurance Supervision Agency), the financial crisis had an indirect effect on Montenegrin insurance market, so it did not endanger the business of insurance companies seriously and neither did it endanger the expectations of policy holders.

The aim of this manuscript is to prove the following hypotheses:

H1: Factors such as age, region, education and employment contribute to life insurance development in Montenegro significantly.

$\mathrm{H} 2$ : the degree of confidence in insurance industry, i.e. higher confidence of citizens in banking system compared to the institution of insurance, as well as gender, have no significant impact on life insurance products purchase.

According to our knowledge, the main contribution of this work is the first research on the analysis of the factors crucial for life insurance in Montenegro. Research results may be useful for Montenegrin financial system institutions due to the fact that insurance companies are important investors, and especially to insurance companies and the institution controlling the insurance market in order to improve it (Insurance Supervision Agency of Montenegro). The final part of the work, preceding the conclusions, shows research results.

\section{Literature review}

Demand for life insurance products depends on different demographic, economics and other factors, as well as factors depending on the insurers themselves (Zietz, 2003). Beck and Webb, (2003) and may other authors (Hwang and Greenford, 2005; Outreville, 1996; Zhuo, 1999) point out to the importance of financial development of the country, social security, inflation rate, citizens income and population on the trends of life insurance.

Yuan and Jiang (2015) analysed factors that affecting the demand of insurance in China. Their results indicate that level 
of income, development of insurance market, level of education, development of social security pension, children dependency ratio and elderly dependency ratio mainly affect the demand for life insurance.

Education is a demographic determinant expected to have a positive impact on demand for insurance products. Liebenberg and Zietz (2003) discovered that published researches show different results for some determinants of life insurance demand, including the education itself. Analysing households in the USA, Hau (2000) also emphasizes that it is unclear whether education affects the demand for life insurance or not. As educational systems vary in different countries and regions, it is a question whether and how deeply the insurance is being investigated from all its three aspects (economic, legal and mathematical) so that the citizens can understand the product of life insurance itself. Treerattanapun (2011) emphasizes that high education is not a guarantee for a person to understand the complexity of life insurance as a product because insurance is not necessarily studied at all universities in detail. Kjosevski (2012) while analysing the determinants of life insurance demand in Central and South Eastern Europe, found that higher level of education leaded to a higher life insurance penetration and higher life insurance density. This finding suggests a need for elevating the education level of population, because it would be useful to enhance the understanding of financial products presented on the market and possible benefits from using them by potential consumers. According to Outrevill (1996), individuals with higher level of education are more aware of the risk and importance of risk management. Therefore, the education does increase risk aversion and encourages the demand for life insurance (Burnett and Palmer, 1984; Truet and Truet, 1990). Also, highly educated people have higher incomes and in long term, they expect the increase of their incomes compared to the citizens with lower educational level, which makes them purchase life insurance. Liebenberg, Carson, and Dumm (2012) concluded that although research results on the impact of education on demand for life insurance are different, managers and other professional and self-employed persons mainly hold a life insurance policy. Further, this leads to the conclusion that the level of economic education does have a significant positive impact on demand for life insurance.

Different studies observe the effect of population aging on economic performances of developed countries (Cutler, et al, 1990). These studies show that population aging has a negative impact on saving (because older people are unable to save). On the other hand, middle aged and older people should be observed as a target group for life insurance (Mantis and Farmer, 1968; Celik and Kayali, 2009). Young people tend to spend more, while middle aged and old people are more aware of risk of death and limited incomes after retirement. In order to secure retirement days in a financial way, or in order to secure their successors in case of their own early death, it can be concluded that population aging may have a positive impact on life insurance demand. Sen and Madheswaran (2013) analysed determinants of life insurance consumption in Asian economies and found that youth dependency ratio was significant determinant of life insurance consumption. Lester, and Rocha (2011), consider that the reason of the positive impact on demand for life insurance is the necessity of employed parents to secure their children against the risk of parents' early death.

Therefore, the relation between life expectancy and demand for life insurance can be ambiguous. One of the reasons is that people with longer life have less need for the insurance against death (lower mortality risk), but they have need savings through life insurance products more, which leads to conclusion that the effect of life expectancy on demand for life insurance depends on the insurance product. Lower mortality risk (longer life expectancy) reduces demand for insurance against death risk and increases the demand for products including the saving component. It can be expected that longer life expectancy has a positive effect on life insurance and decrease of insurance price. Most empirical cross-country studies show that longer life expectancy has a positive impact on life insurance, but with no statistical significance (Outreville, 1996; Ward and Zurbruegg, 2000; Lim and Haberman, 2003; Li et al. 2007; Sen, 2008; Feyen et al., 2011).

Luciano at al. (2016) analysed life insurance ownership by Italian households and found out the differences between two types of contracts, traditional life and term life insurance. They showed that, in all cases, women were less likely to be insured than are men.

On average, citizens from urban environment are more familiar with risk and risk management, compared to those living in rural areas, which indicates to the positive effect of urban development on life insurance demand (Beck and Webb, 2003). Dragos (2014) showed that urban development has a significant impact on demand for life insurance in Asia, but not in Europe. Sen and Madheswaran (2007) and Sen (2008) discovered that in 13 Asian economies, there was a positive relation between urban development and demand for life insurance products. Nesterova (2008), based on the study from Central Eastern Europe (CEE) and some countries from former Soviet Union, showed that the level of urban development had no significance for life insurance demand. Zerriaa and Noubbigh (2016), based on the study from Middle East and North Africa region, also showed that urbanisation did not appear to influence life insurance demand.

The research carried out by audit-consulting company Ernest Young „2014 Global Customer Insurance Survey“, showed that the interviewed citizens of 30 European countries also have more confidence in banks compared to insurance companies because insurers rarely communicate with policy holders ${ }^{4}$.

4 Svet osiguranja, No. 12, December 2014., p.11 
More precisely, potential policy holders expect a more significant and direct communication with their insurers. Regarding the specificity of bank products, banks have stable contacts with their customers and as a result of this kind of relations; there is a possibility of the reestablishment of confidence even if it has been broken before. However, insurers both in Montenegro and in other European countries, have a very weak contact with policy holders which make the establishment of confidence and reliable and long-term relations difficult.

\section{Research Methodology and Data Description}

The chi square test is a statistical test applied to sets of categorical variables to evaluate whether distribution of one variable depends on other variable's distribution or not. It usually serves as a test for the common contingency table, and enables comparison between actually observed frequencies and those expected according to the theoretical model, or to a hypothesis about the distribution of the characteristics concerned. Category of first variable is placed in $i^{\text {th }}$ row, $i=1,2, \ldots, r$ and category of second variable is in $j^{\text {th }}$ column, where $j=1,2, \ldots, c$.

The chi square statistic is defined as

$$
\chi^{2}=\sum_{i} \sum_{j} \frac{\left(O_{i j}-E_{i j}\right)^{2}}{E_{i j}}
$$

where $O_{i j}$ is the observed number of cases in category $i$ of first variable and category $j$ of second variable, and $E_{i j}$ is the expected number of cases in category $I$, of first variable and category $j$ of second variable. The expected frequency under the null hypothesis is calculated by

$$
E_{i j}=\frac{r_{i} c_{j}}{n}
$$

Where $r_{i}$ is a sum of observed numbers of cases in $i^{\text {th }}$ row, $c_{j}$ a sum of observed numbers of cases in $j^{\text {th }}$ column and $n$ is a total number in the contingency table.

The null hypothesis claims the observed and the expected values are close to each other and its difference is small for each category. When the observed data do not conform to what has been expected on the basis of the null hypothesis, the difference between the observed and expected values is large. The chi square statistic is compared to critical value of chi square distribution with $(r-1)(c-1)$ degrees of freedom, and if calculated value is higher than critical value, the null hypothesis is rejected ( $r$ is a number of rows and $c$ is a number of columns in the contingency table).

The regression analysis is then conducted in order to test the statistical significance of the effect of the variables used on the life insured population.

The research on acceptance of life insurance was carried out by a survey whose main objective was to determine the factors affecting insufficient representation of life insurance in total insurance market. 380 citizens were interviewed. Data collection took 3 months in the period September - December 2015. The investigation was conducted based on the opinion of employees and other individuals separately (students, unemployed persons and retired persons). Using a field survey method, 209 employed persons and 168 other respondents were examined. The stratification of the sample was carried out on the basis of region and type of settlement (urban and rural), while post-stratification was performed on the basis of age, gender, education and employment. The questionnaire consists of several parts. The first part of questionnaire contains data on the demographic characteristics of citizens. The second part reveils data on the employment of citizens, and this part of the questionnaire was filled only by employees. The third part of the questionnaire indicates how many people (employees and others) are familiar with life insurance, or how many of them are familiar with the advantages of this product. The fourth part of the survey indicates whether respondents are insured or not, and the reasons if they have or not a life insurance policy. The last part of the survey responds whether the respondents are planning to buy life insurance in the future and states the conditions if planning.

Based on the interview of Montenegrin citizens on significance and understanding of life insurance products, it was concluded that only 5\% of interviewed Montenegrin citizens have high confidence in insurance industry and that majority of them (51\%) have more confidence in savings through banks compared to savings through life insurance products (Figs. 1 and 2).

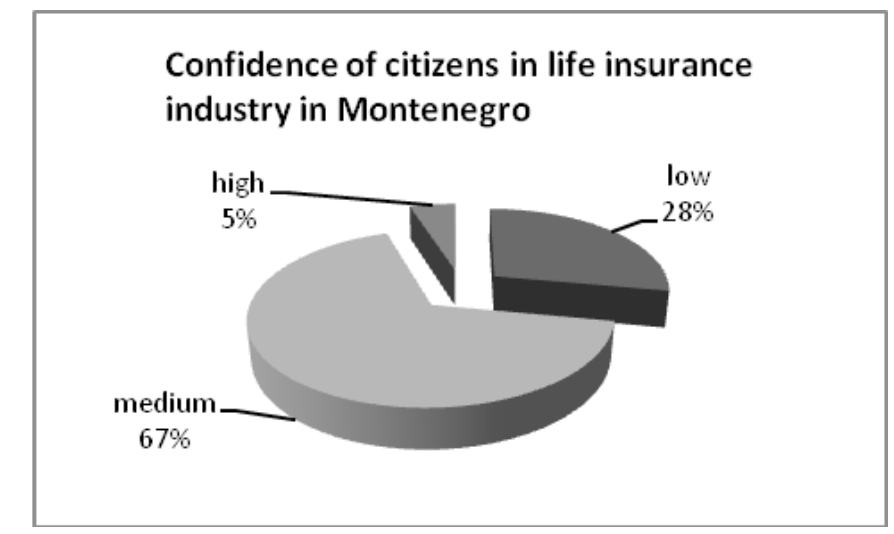

Fig. 1 Confidence of citizens in life insurance industry in Montenegro

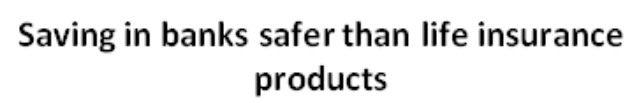

Yes No

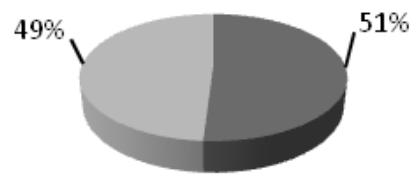

Fig. 2 Saving in banks vs. life insurance products in Montenegro 
Interview results clearly showed that life standard of the population limits both the sum and dynamics of premium payment, i.e. affects the trends of insurance market indicators. Result shows that $70.1 \%$ of the interviewed people are ready to pay minimum yearly life insurance premium, whose sum depends on the politics of the insurance company and the insurance product itself, while only $1 \%$ of the interviewed are able to afford, for example, yearly life insurance premium of $2000 €$. Also, 34\% of the interviewed people were able to pay life insurance premium for a 10 -year period, $57 \%$ for $10-20$ years and 19\% longer than 20 years.

Although insurance premium, i.e. purchasing power of the population, is key factor of the motivation for majority of potential policy holders, frequent communication with policy holders, i.e. an adequate and timely awareness which increases the level of confidence in insurance institutions is crucial for the positioning of insurers on the market and the strengthening of the insurance market itself.

Besides promotional activities, the representation of these issues in the educational system itself also has a significant influence on citizens' awareness of the importance of life insurance. Accordingly, the research has shown that educated population in Montenegro, especially those with a degree in economics, and whose incomes are higher than those of less educated citizens, more often decide to purchase life insurance products (Fig. 3). Also, observing the development stage of different Montenegrin regions, the least number of policy holders is from Northern region, characterized by lower urban development level, i.e. most policy holders are from South regions $-47 \%$ (with the highest level of urban development), which was shown by the results of the interview carried out among population of Montenegro (Fig. 4).

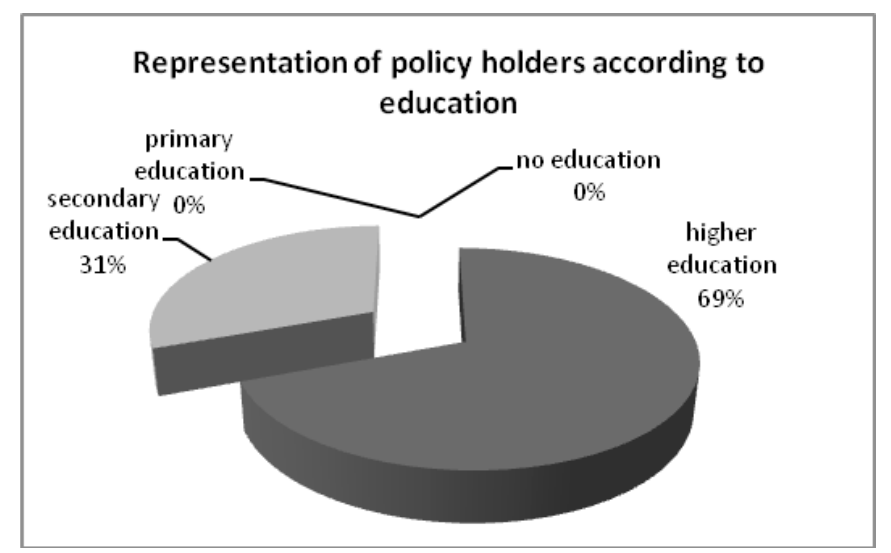

Fig. 3 Representation of Montenegrin policy holders according to education

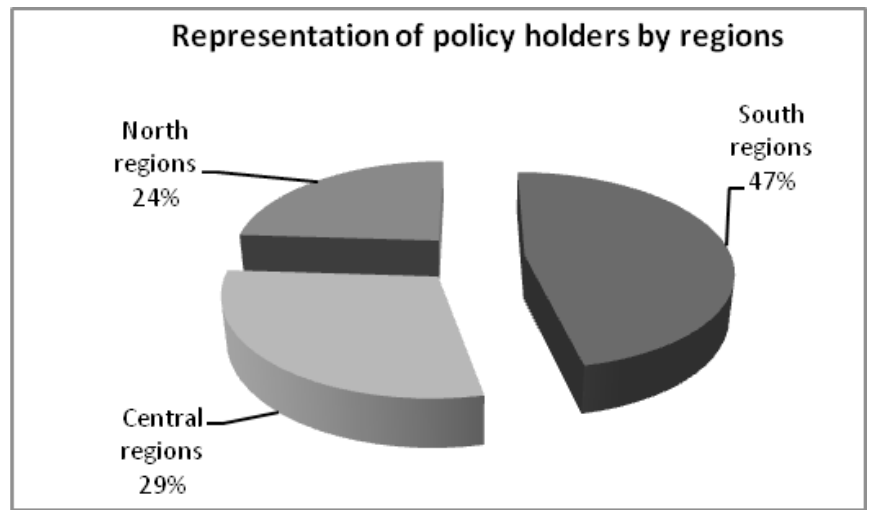

Fig. 4 Representation of Montenegrin policy holders by regions

Among total number of respondents, most belong to the category of middle aged citizens $-42 \%$. Old population (over 60 years old) has the lowest share in the observed sample - only $4 \%$. This result is justified because older population actually has the least amount of work related activities and their financial funds are insufficient (low wages and pensions), so they cannot allocate funds to savings. On the other hand, younger population due to educational level and higher awareness of the benefits of life insurance, show strong tendency toward life insurance products (Fig. 5).

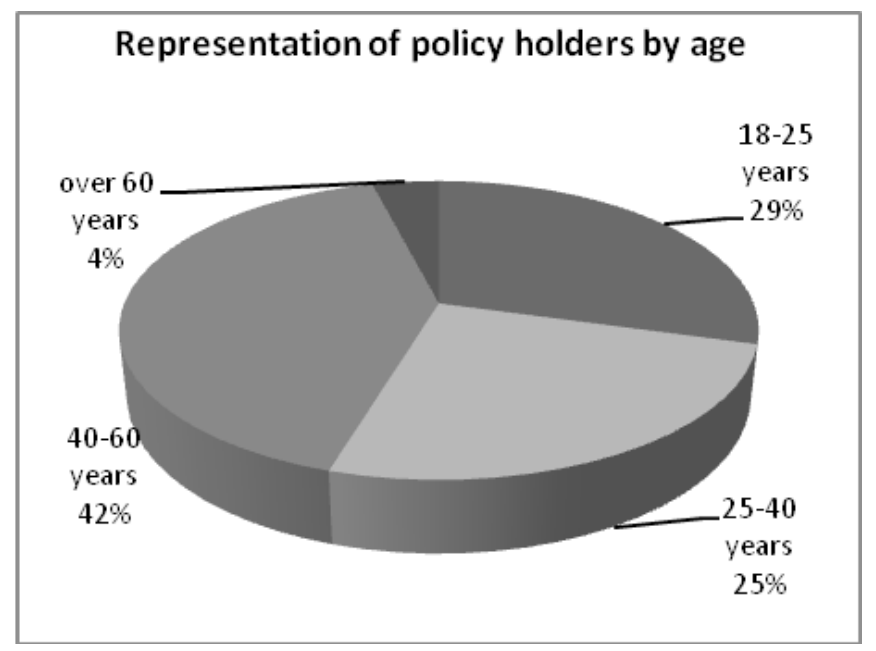

Fig. 5 Representation of Montenegrin policy holders by age

\section{Empirical Results}

We have conducted chi square tests of independence, in order to examine whether there is dependence between life-insured population, on one side, and employment, age, education, region, and trust in financial system and opinion that savings in banks are more secure than life insurance, on the other side. The results are given in the following tables.

Table 1 shows the influence of employment on the purchase of life insurance. The largest number of the respondents in this survey is employed and more than half of them do not buy life insurance. Out of total of 168 unemployed, only 20 individuals 
purchase life insurance. The results of the chi square test at $5 \%$ significant level are presented in Table 2 . Since the p-value $(0.000)$ is less than the significance level $(0.05)$, we cannot accept the null hypothesis of chi square test in Table 2. Thus, we conclude that there is a significant relationship between employment and life-insured population. Namely, employment positively influences life insurance, because employed individuals receive income and have funds to buy life insurance.

Table 1 Employment -Life insurance Crosstabulation

\begin{tabular}{lcccc}
\hline & & \multicolumn{2}{c}{ Life insured } & \multirow{2}{*}{ Total } \\
\cline { 3 - 4 } & & Yes & No & \\
\hline \multirow{2}{*}{ Employment } & Yes & 55 & 154 & 209 \\
& No & 20 & 148 & 168 \\
\hline Total & & 75 & 302 & 377 \\
\hline
\end{tabular}

Table 2 Pearson Chi-Square Tests

\begin{tabular}{llll}
\hline Variables & Value & df & $\begin{array}{l}\text { Asymp Sig. } \\
(2 \text {-sided })\end{array}$ \\
\hline Employment & 12.137 & 1 & .000 \\
Age & 10.138 & 3 & .017 \\
Education & 6.781 & 2 & .034 \\
Trust - Life Insurance & .540 & 2 & .763 \\
Savings are more secure & 1.934 & 1 & .164 \\
than life insurance & & & .055 \\
Region & 5.800 & 2 & \\
\hline
\end{tabular}

The relationship between the age, divided into four classes, and life insurance is presented in Table 3. The largest number of respondents - 142 out of total of 377 , belongs to the age group 18-25 years. The smallest number of respondents is in the age group of more than 60 years. More than $80 \%$ of the respondents did not purchase life insurance and the largest number of them is in the age group 18-25 years. Out of 142 respondents in the age group 18-25 years, only 22 bought life insurance. The most numerous buyers of life insurance are individuals in the age group 40-60 years. One out of six respondents in the age group of 60 years and more, buy life insurance. In order to determine the link between the age and life insurance, the chi square test is conducted, at the significance level of 5 percent. The obtained results are presented in the Table 2 . Since $p$-value is less than 5 percent the null hypothesis of no relationship between the age of the respondents and life insurance is rejected. Different age groups of the individuals behave differently regarding the life insurance purchase. Their life insurance purchase is in accordance with the life-cycle theory due to income variability during the individuals' lifetime. A relationship between life insured population and age is not significant at significant level of $1 \%$, since p-value is 0.017 , but is significant at significant level of $5 \%$.
Table 3 Age -Life insurance Crosstabulation

\begin{tabular}{lllll}
\hline & & \multicolumn{2}{c}{ Life insured } & \multirow{2}{*}{ Total } \\
\cline { 3 - 4 } & & Yes & No & \\
\hline \multirow{3}{*}{ Age } & 18-25 years & 22 & 120 & 142 \\
& 25-40 years & 19 & 96 & 115 \\
& 40-60 years & 31 & 70 & 101 \\
& More than 60 & 3 & 16 & 19 \\
\hline
\end{tabular}

The next analysed determinant is education. The relationship between the education and life insurance is presented in Table 4. The largest number of the respondents in the survey has higher education, and the smallest number has qualifications of primary education. Almost $20 \%$ of the total respondents purchased life insurance. The results of chi square test of link between the education and life insurance demand at the level of significance of $5 \%$ are shown in Table 2. Due to the $p$-value, null hypothesis is rejected. Thus, there is a significant relationship between the education and life insurance. In other words, differently educated people do not equally buy life insurance. This confirms that individuals with higher education are more familiar with life insurance.

Table 4 Education - Life Insurance Crosstabulation

\begin{tabular}{|c|c|c|c|c|}
\hline & & \multicolumn{2}{|c|}{ Life insured } & \multirow{2}{*}{ Total } \\
\hline & & Yes & No & \\
\hline \multirow{3}{*}{ Education } & Higher & 52 & 161 & 213 \\
\hline & Secondary & 23 & 137 & 160 \\
\hline & Primary & 0 & 4 & 4 \\
\hline Total & & 75 & 302 & 377 \\
\hline
\end{tabular}

Trust in insurance system is next determinant whose influence on life insurance is analysed and the observed results are presented in Table 5. Out of total number of the respondents, only 2 are life-insured and the rest of 299 respondents did not buy life insurance. More than two thirds of the respondents have medium trust in insurance system, and only single respondent from that group purchased life insurance. The results of the chi square test are shown in Table 2, indicating that there is no relationship between trust in insurance system and life insurance. There is no evidence that different trust in insurance system influenced purchase of life insurance.

Table 5 Trust - Life Insurance Crosstabulation

\begin{tabular}{lllll}
\hline & & \multicolumn{2}{c}{ Life insured } & \\
\cline { 3 - 4 } & & Yes & No & Total \\
\hline \multirow{3}{*}{ Trust } & Low & 1 & 83 & 84 \\
& Medium & 1 & 201 & 202 \\
& High & 0 & 15 & 15 \\
\hline \multirow{2}{*}{ Total } & & 2 & 299 & 301 \\
\hline
\end{tabular}


We also investigated whether opinion of respondents that savings in banks are more secure than life insurance influences purchase of life insurance. The link between life insurance and this opinion is presented in Table 6. About half of respondents think that savings in banks are more secure than life insurance. Again, only 2 out of all respondents buy life insurance. Based on the results of chi square test, shown in Table 2, null hypothesis cannot be rejected, meaning there is no relationship between two variables - Opinion that savings in banks are more secure than life insurance and life insurance. The result of this test can be explained by the fact that life insurance has been developing seriously only since 2006 in Montenegro, so the majority of citizens is not familiar with life insurance products, covered risks and payments which are paid by insurance companies to policy holders if the insured event occurs, which is not the case with banks as deposit interest rate can be easily determined. In other words, the respondents consider banks safer than insurance companies due to the predictability of time and sum of payout at banks, possibility of more frequent communication with one's bankers, as well as better awareness of banking products compared to life insurance products.

Table 6 Savings in banks vs. Life insurance -Life Insurance Crosstabulation

\begin{tabular}{lcccc}
\hline & & \multicolumn{3}{c}{ Life insured } \\
\cline { 3 - 4 } & & Yes & No & \\
\hline Savings are more & Yes & 2 & 151 & 153 \\
secure than life insurance & No & 0 & 147 & 147 \\
\hline Total & & 2 & 298 & 300 \\
\hline
\end{tabular}

Region of the country where respondents live is next demographic determinant whose influence on life insurance is analysed and the observed results are presented in Table 7. Out of total number of the respondents, 133 belong to the southern region, 121 are from central region and 123 are from the North. About one fourth of respondents from South purchase life insurance, while that proportion in group of respondents from Central and North is somewhat smaller. The results of the chi square test are shown in Table 2, indicating that there is no significant difference in purchasing life insurance among regions of Montenegro. The result of this test can be confirmed due to insufficient development of life insurance in Montenegro on one hand, and equal willingness, i.e. the lack of willingness of citizens to save through insurance institutions on the other hand.

Table 7 Region - Life Insurance Crosstabulation

\begin{tabular}{lllll}
\hline & & \multicolumn{2}{c}{ Life insured } & \\
\cline { 3 - 4 } & & Yes & No & \\
\hline \multirow{3}{*}{ Region } & South & 35 & 98 & 133 \\
& Central & 22 & 99 & 121 \\
& North & 18 & 105 & 123 \\
\hline \multirow{2}{*}{ Total } & & 75 & 302 & 377 \\
\hline
\end{tabular}

In order to additionally explore whether the analyzed factors, (such as level of education, employment and others), affect the demand for life insurance, we tested the significance of the coefficients through the regression analysis in which the mentioned factors are independent variables, while data series that records the status of the respondents in terms of insurance - the dependent variable. By this test we observed whether the region and gender have an impact on the decision of the citizens about the purchase of life insurance policies. The model clearly shows that factors such as level of education and employment have significant positive impact on the decision whether the respondent to buy a life insurance policy (probability is less than 0.05), while factors such as gender and region have no statistical significance (probability is greater than 0.05 ). The test results are shown in Table 8 .

Table 8 The results of the regression model

\begin{tabular}{lcccc}
\hline \multicolumn{4}{c}{ Dependent Variable: Life Insured Population (Yes/No) } \\
\hline Variable & Coefficient & Std. Error & t-Statistic & Prob. \\
Education & 0.091582 & 0.039670 & 2.308604 & 0.0215 \\
Employment & 0.108915 & 0.044570 & 2.443707 & 0.0150 \\
Region & 0.039019 & 0.026539 & 1.470284 & 0.1423 \\
Gender & 0.019266 & 0.041902 & 0.459800 & 0.6459 \\
C & 1.402630 & 0.115350 & 12.15979 & 0.0000 \\
\hline
\end{tabular}

\section{Conclusion}

Research results show that demand for life insurance in Montenegro depends on age structure and education as demographic factors, and level of employment as economic factor.

Most life insurance policy holders belong to middle aged population, which can be explained by the availability of financial funds and necessity to secure their successors for the case of death risk realization, but also to secure them for old age. On the other hand, young population, especially the employed part of it and with adequate educational background, is ready to invest certain amount of financial funds in the purchase of insurance policies. Older population, mostly due to the lack of financial funds, as well as due to high premium expenses because of death risk growth cannot afford to purchase life insurance products. Observing Montenegro where 10\% of graduated students are actually graduated economy students, it is clear that economic education gives best contribution to life insurance development. This kind of education is the best way for students to learn about functions and importance of insurance, specificities of expenses and insurance fees, and therefore unlike uneducated people, as well as the people of different educational profiles, they more preferably decide to purchase life insurance products.

Higher employment rate, growth of personal incomes and general improvement of life standard in Montenegro, will have a significant positive impact on further development of life 
insurance. Due to higher incomes, younger and more educated generation, especially those with adequate employment, will be able to afford to allocate a part of their incomes to life insurance products purchasing.

More precisely, analysis results have shown there is a significant contribution of all factors listed in hypothesis 1 to the development of life insurance, except regional factors. However, these results partially prove the first hypothesis, while regional factors are rejected as statistically insignificant for life insurance development.

The differences in the share of policy holders by regions are statistically insignificant at confidence level of 95\% although most respondents who own a life insurance policy are from the South of Montenegro as the most developed region and the least are from the least developed area, i.e. north. Due to low life standard in Montenegro, unemployment problem and other unfavourable economic indicators caused by the economic crisis in the previous decade, life insurance has been on a low level and therefore the distribution of policy holders by regions of the country has no statistical significance for life insurance. Regression model also confirmed that the region has no influence on the decision of the population of Montenegro about demand for life insurance.

The level of confidence in insurance industry among Montenegrin population, as well as a higher degree of confidence in investments of financial funds in banks, compared to insurance companies, has no statistical significance for the purchase of life insurance products in Montenegro, which proved the hypothesis 2 . The impact of gender is also included in this hypothesis, and by regression model, we finally confirmed the accuracy of our second research hypothesis that gender has no significant effect on the population decision about life insurance.

Since compulsory insurance is predominant in total insurance portfolio of Montenegro, i.e. non-life compared to life insurance, the experience of citizens regarding the dynamics and payout sum based on insurance policy are different and mainly connected with non-life insurance products. On the other hand, life insurance has been developing seriously since 2006 in Montenegro. Also, life insurance contracts are concluded for the periods of 10 years or longer, which leads to the conclusion that the effect of this factor on the trend of life insurance purchase should be analysed in more detail in the following period. More precisely, due to predominance of compulsory and non-life insurance products and still insufficient experience when it comes to benefits of life insurance products, the research result showing that citizens' confidence in insurance industry does not contribute to the trend of life insurance products purchasing is justified.

If we emphasize that financial market in Montenegro is bank-centric and that the banks have a constant dominant position in the whole financial system of Montenegro compared to insurance companies, but also other institutional investors (voluntary pension funds and invest funds), it can be expected that citizens have more confidence in banks than in insurance companies. If we take into account the fact that passive deposit interest rates have been on a low level for many years now and that the pay out of life insurance products depends on guaranteed interest rate, age and income realized by insurance companies on financial market, it can be concluded that citizens separate the advantages and disadvantages of banking products from life insurance products more and more. This can further justify the statistic result of the research regarding the impact of citizens' level of confidence in banking system on the development of life insurance market.

Finally, we can conclude that analysed factors significantly condition the dynamics of development of life insurance in Montenegro. However, besides these factors, there are many more, such as development level of financial sector, application of regulations in insurance sector with the aim to enter the uniform European market, promotion of products and channels for life insurance selling etc., which can also affect further expansion of life insurance in Montenegro. This can be an interesting topic for some other research in future.

\section{References}

Bacovic, M. (2007). Demographic Changes in transition countries: Opportunity or Obstacle for Economic Growth? Case of Montenegro. European Research Studies. 11(3-4), pp. 31-44.

Baletić-Wertheimer, A. (1999). Stanovništvo i razvoj. (Population and Development.), Zagreb, MATE. (in Croatian)

Beck, T., Webb, I. (2003). Economic, demographic and institutional determinants of life insurance consumption across Countries. The World Bank Economic Review. 17(1), pp. 51-87.

Becker, G., Murphy, K., Tamura, R. (1990): Human Capital, Fertility, and Economic Growth. The Journal of Political Economy. 98(5), Part 2., pp. S12-S37.

Birdsall, N. (1977). Analytical Approaches to the Relationship of Population Growth and Development. Population and Development Review. 3(1/2), pp. 63-102. https://doi.org/10.2307/1971760

Browne, M. J., Kim, K. (1993). An International Analysis of Life Insurance Demand. The Journal of Risk and Insurance. 60(4), pp. 616-634. https://doi.org/10.2307/253382

Burnett, J. J., Palmer, B. A. (1984). Examining Life Insurance Ownership through Demographic and Psychographic Characteristics. The Journal of Risk and Insurance. 51(3), pp. 453-467. https://doi.org/10.2307/252479

Çelik, S., Kayali, M. M. (2009). Determinants of demand for life insurance in European countries. Problems and Perspectives in Management. 7(3), pp. 32-37.

Chee, L. (2013). Examining the New Purchase of Whole Life, Endowment and Temporary Insurance through Macro-level Demographic Factors: The Case of Malaysia. Procedia - Social and Behavioral Sciences. 91, pp. 306-315. https://doi.org/10.1016/j.sbspro.2013.08.427

Cutler, D. M., Poterba, J. M., Sheiner, L. M., Summers, L. H. (1990). An Aging Society: Opportunity or Challenge. Brookings Papers on Economic Activity. (1), pp. 1-73. 
Dragos, S. L. (2014). Life and non-life insurance demand: the different effects of influence factors in emerging countries from Europe and Asia. Economic Research-Ekonomska Istraživanja. 27(1), pp. 169-180.

https://doi.org/10.1080/1331677X.2014.952112

Feyen, E., Lester, R., Rocha, R. (2011). What drives the development of the insurance sector? An empirical analysis based on a panel of developed and developing Countries. Policyresearch working paper presented at The World Bank. no 5572. URL: https://openknowledge.worldbank.org/ bitstream/handle/10986/3339/WPS5572.pdf? sequence=4\&isAllowed=y

Hau, A. (2000). Liquidity, estate liquidation, charitable motives and life insurance demand by retired singles. The Journal of Risk and Insurance. 67(1), pp. 123-141. https://doi.org/10.2307/253680

Hwang, T., Greenford, B. (2005). A Cross-Section Analysis of the Determinants of Life Insurance Consumption in Mainland China, Hong Kong, and Taiwan. Risk Management and Insurance Review. 8(1), pp. 103-125. https://doi.org/10.1111/j.1540-6296.2005.00051.x

Kascelan, V., Novovic, M. (2009). Osiguranjeiaktuarska matematika. (Insurance and Actuarial Mathematics.) Podgorica Univerzitet Crne Gore. (in Serbian)

Kjosevski, J. (2012). The determinants of life insurance demand in central and Southeastern Europe. International Journal of Economics and Finance. 4(3), pp. 237-247. https://doi.org/10.5539/ijef.v4n3p237

Li, D., Moshirian, F., Nguyen, P., Wee, T. (2007): The Demand for Life Insurance in OECD Countries. The Journal of Risk and Insurance. 74(3), pp. 637-652. https://doi.org/10.1111/j.1539-6975.2007.00228.x

Liebenberg, A. P., Carson, J. M., Dumm, R. E. (2012). A dynamic analysis of the demand for life insurance. The Journal of Risk and Insurance. 79(3), pp. 619-644. https://doi.org/10.1111/j.1539-6975.2011.01454.x

Lim, C. C., Haberman, S. (2003). Macroeconomic Variables and the Demand for Life Insurance in Malaysia. Faculty of Actuarial Science and Statistics, City University London, Cass Business School. Paper presented at the Oxmetrics Conference. URL: https://www.cass.city.ac.uk/_data/ assets/pdf_file/0010/65278/LimHaberman29August.pdf

Luciano, E., Outreville, J. F., Rossi M. (2016). Life Insurance Ownership by Italian Households: A Gender-Based Differences Analysis. The Geneva Papers on Risk and Insurance - Issues and Practice. 41(3), pp. 468-490.

Mantis, G., Farmer, R. (1968). Demand for Life Insurance. The Journal of Risk and Insurance. 35(2), pp. 247-256.

Nesterova, D. (2008). Determinants of the demand for life insurance: Evidence from selected CIS and CEE Countries. Master thesis. National University "Kyiv-Mohyla Academy". pp. 1-49. URL: http://www.kse.org.ua/ uploads/file/library/2008/nesterova.pdf

Ofoghi, R., Farsangi, R. H. (2013). The effect of insurance knowledge on the insurance demand: The case study of auto insurance. Technical Journal of Engineering and Applied Sciences. 3(23), pp. 3356-3364.
Outreville, F. J. (1996). Life Insurance Markets in Developing Countries. The Journal of Risk and Insurance. 63(2). pp. 263-278. https://doi.org/10.2307/253745

Outreville, F. J. (2015). The relationship between relative risk aversion and the level of education: a survey and implications for the demand for life insurance. Journal of Economic Surveys. 29(1), pp. 97-111. https://doi.org/10.1111/joes. 12050

Pradhan, P. R., Arvin, B. M, Norman, R. N. (2015). Insurance development and the finance-growth nexus: Evidence from $34 \mathrm{OECD}$ countries. Journal of Multinational Financial Management. 31, pp. 1-22. https://doi.org/10.1016/j.mulfin.2015.02.001

Rowland, D. (2003). Demographic Methods and Concepts. USA, Oxford University Press.

Sen, S., Madheswaran, S. (2007). Are life insurance demand determinants valid for selected Asian economies and India?. Paper for Presentation at Annual Meeting of APRIA.

Sen, S., Madheswaran, S. (2013). Regional determinants of life insurance consumption: evidence from selected Asian economies. Asian-Pacific Economic Literature. 27(2), pp. 86-103. https://doi.org/10.1111/apel.12024

Treerattanapun, A. (2011). The impact of culture on non-life insurance consumption. Paper presented at Wharton Research Scholars Project. The University of Pennsylvania. URL: http://repository.upenn.edu/cgi/viewcontent.cgi? article $=1078 \&$ context $=$ wharton_research_scholars

Truett, D. B., Truett, L. J. (1990). The Demand for Life Insurance in Mexico and the United States: A Comparative Study. The Journal of Risk and Insurance. 57(2), pp. 321-328. https://doi.org/10.2307/253306

Ward, D., Zurbruegg, R. (2000). Does Insurance Promote Economic Growth? Evidence from OECD Countries. The Journal of Risk and Insurance. 67(4), pp. 489-506. https://doi.org/10.2307/253847

Yuan, C., Jiang, Y. (2015). Factors affecting the demand for insurance in China. Applied Economics. 47(45), pp. 4855-4867. https://doi.org/10.1080/00036846.2015.1037437

Zerriaa, M., Noubbigh, H. (2016). Determinants of Life Insurance Demand in the MENA Region. The Geneva Papers on Risk and Insurance - Issues and Practice. 41(3), pp. 491-511. https://doi.org/10.1057/gpp.2016.1

Zhuo, Z. (1999). Demand for Life Insurance: An Empirical Analysis on China. Zeitschrift fur Versicherungwesen. (6-7), pp. 323-326.

Zietz, E. N. (2003). An examination of the demand for life insurance. Risk Management and Insurance Review. 6(2), pp. 159-191. https://doi.org/10.1046/J.1098-1616.2003.030.x 